\title{
Students' reasons for wanting to teach in primary school
}

\author{
Mary Thornton and Pat Bricheno University of Hertfordshire \\ Ivan Reid University of Bradford
}

Despite the introduction of training salaries for Postgraduate Certificate of Education (PGCE) students, a substantial increase in enquiries (Tabberer, 2000) and some reported increase in the actual number of applications

for primary teacher education courses (Campbell, 2000), recruitment overall has declined significantly, from 24,994 applications in 1994 to 9,875 in 1999 (Gates, 1999). Higher entry qualifications will not readily be imposed on a

smaller pool of applicants if the educational characteristics of those applicants remain at the same level (generally considered to be low: House of Commons, 1997). Specific subject-knowledge for teaching may be enhanced by increased emphasis on first degrees and thus recruitment to primary PGCE courses, through the discriminating allocation of training salaries and as an outcome of the Secretary of State's description of the Bachelor of Education (B.Ed.) degree as a 'sub-degree undergraduate course' (McAvoy, citing Hansard, 2000), but the PGCE neither ensures adequate coverage of shortage subjects nor the whole curriculum competence required of most primary teachers (Thornton, 1998). Despite the introduction of training salaries for PGCE students, starting in September 2000, recruitment of ethnic minority and male students remains low (Barnard, 2000, reports just a 5 per cent increase in applications from men and a 5 per cent increase in enquiries from ethnic minorities) and there is strong evidence that the teaching profession in England is becoming increasingly feminised (Howson, 1998).

The extant literature contains examples of research into the nature of teachers' work in England (Nias et al., 1989; Campbell and Neill, 1994), the restrictions hegemonic masculinity imposes on educative and career options for males (Mac an Ghaill, 1994; Kenway and Willis, 1998; Connell, 1987) and the experience of men working in predominantly female occupations (Ruxton, 1992; Allen, 1993; Penn and McQuail, 1997; Owen et al., 1998) in England, the United States and Australia. There are also some small-scale qualitative studies of primary teachers (Boulton and Coldron, 1998; Evans, 1998; Skelton, 1991; Jones, 1990). However, no relevant data on primary teaching as a career choice in England have been found, although Johnston et al. (1998) have studied gender factors in choosing primary teaching in Northern Ireland. Thus the present policy debate regarding recruitment into primary teaching (DfEE, 1998) is based on little hard evidence.

This article records the views of many students who had been successfully recruited to primary initial teacher education (ITE) courses, both undergraduate and postgraduate, in England in September 1998. In doing so it provides, first, an in-depth insight into the motivations and concerns of students training to be primary school teachers, and, second, some hard evidence to inform the debate around English primary school teacher recruitment strategies. 


\section{Sample and method}

In autumn 1998 a questionnaire survey of newly recruited primary ITE students was conducted, producing a data set of 1,611 questionnaire responses. These primary teaching students, PGCE and firstyear undergraduates, were drawn from fourteen different higher education institutions (HEIs). The survey was followed during spring and summer 1999 by interviews with 148 student volunteers. The institutional sample was broadly representative of the HEI training providers in England and the gender sample for both the questionnaire survey and the interviews was very close to the current intake figures of approximately 15 per cent male, 85 per cent female (Table 1). While 53 per cent of the questionnaire respondents were undergraduates and 47 per cent postgraduates, this slight imbalance was reversed in terms of interviewees, 45 per cent being undergraduates and 55 per cent postgraduates.

Table 1 Percentages of those in the survey who offered to be, and were, interviewed

\begin{tabular}{lcccccr} 
& \multicolumn{2}{c}{$\begin{array}{c}\text { Responded to } \\
\text { questionnaire }\end{array}$} & \multicolumn{2}{c}{ Offered to be } & \multicolumn{2}{c}{ Actually } \\
\cline { 2 - 5 } Category & \multicolumn{2}{c}{$n \%$} & \multicolumn{2}{c}{$n \%$} & \multicolumn{2}{c}{ interviewed } \\
Male & 193 & 12 & 59 & 17 & 22 & 15 \\
Female & 1,394 & 87 & 293 & 82 & 126 & 85 \\
Unknown & 24 & 1 & 4 & 1 & 0 & 0 \\
Total & 1,611 & 100 & 356 & 100 & 148 & 100 \\
Undergraduates & 850 & 53 & 185 & 52 & 67 & 45 \\
Postgraduates & 761 & 47 & 171 & 48 & 81 & 55 \\
Total & 1,611 & 100 & 356 & 100 & 148 & 100
\end{tabular}

The questionnaire asked students to indicate the importance, or otherwise, of a given set of reasons for: wanting to become a teacher; not wanting a job other than teaching; their choice of primary school teaching; not choosing to train for secondary school, and the influences on them in deciding to embark on their training course. The students were asked to choose between 'very important', 'important', 'not important' and 'not considered' for each of the given set of reasons.

The interview schedule was designed to gain further depth to the reasoning behind the choice of important factors in respect to the reasons listed. Hence in interview students were requested to choose, from those they had indicated as 'very important' or, in cases where this category had not been used, 'important', the most important single item in their consideration.

They were then asked to explain why this item was the most important. In addition, the opportunity was taken to collect further data from the respondents, e.g. whether they had considered alternative routes into primary teaching; whether they chose A levels/degree subjects with primary teaching in mind; whether they had any reservations about primary teaching as a career; whether the teachers they had met in school while on the course had been positive about the job; whether any members of their family were or had been teachers; what they thought might encourage, or put people off, becoming primary teachers; whether they had basic knowledge about the Teacher Training Agency (TTA) and its recruitment advertisements and what their reactions were to them. The findings reported here relate to students' reservations, if any, about primary teaching as a career and what they 
thought might encourage people to become teachers and what might put them off. They are illustrated through extracts from case-study interviews with three students. For full discussion of all the findings see Reid and Thornton (2000).

Students who had volunteered were invited by mail to choose to be interviewed face to face by the researchers, or by telephone or via e-mail (for which a variant of the interview schedule was used). Mainly because of the varying timetables of the courses and the placement of students in schools, the collection of this fieldwork data spanned from March through to the second week of June 1999. The interview data were transcribed into a format that facilitated analysis by QSR NU*DIST (Richards and Richards, 1997).

This enabled responses to each of the questions to be categorised. Summaries of the categorisations are given below. Clearly the interviewed students were a self-selected group from among those successfully recruited into the profession of primary school teaching. The findings presented here should be viewed in that context. Quotations have been used both to display the range of students' thinking and the individual contexts in which it is located.

\section{Why primary teaching?}

The outcomes of this research, both survey and interviews, were that virtually all those successfully recruited claimed that they had always wanted to teach, really enjoyed working with children and felt that teaching would bring high job satisfaction, would be a good career and would be a challenge (Reid and Thornton, 2000). They were 'pulled' towards teaching as a career for very positive, often altruistic reasons.

\section{'Pull' factors into primary teaching}

Gina. I think for me I was going to go for teaching .... a good career, prospects and financial-wise .... I had a lot of experience in teaching that involved working with children. I think that was the main reason, that was the prior reason. I was doing another course and I took a year out because it wasn't what I wanted basically to do, and that year out I was teaching, and I felt: this is what I want to do, this is what I really enjoy, and I think with teaching you either enjoy it or you don't ... I just enjoy working with children and I think that's what made me go into teaching ... I really enjoy it and it motivates me as a person and I think if you're really motivated by something you tend to be a lot better at what you're doing.

Angela. I would say because I enjoy working with children and I want to improve children's life chances, which is a bit idealistic, and I thought it would also bring a high degree of job satisfaction .... I like children's company.

I find them very entertaining and stimulating. I've got two children of my own and, you know, compared with what I used to do as an architect - well, I like being with children.

Guy. The job satisfaction is most important for me .... I'm one of these strange people who feel they're here for a reason. I want to make a difference. I want to be working and helping people ... doing something like that. The job is ... you're working with people, helping people. You're interacting and you can make a difference, so that's why I did Environmental Science, to try .... I'm a bit of a dreamer, I suppose. I feel that I can make a difference, but I do genuinely believe as a teacher ... you can change people's lives for the better and for the worse. Hopefully for the better, but I do genuinely believe that. I gave up a good job in industry because I didn't feel that, you know, I can't explain it, but you just have this feeling that there's more to life than just working in an office. You've got to be doing something, you've got to be making a difference.

These students' comments capture the very positive feelings that the successfully recruited experienced in relation to their choice of teaching as a career. It was rewarding, challenging and varied. A greater emphasis on the positive features of teaching, in the English press and from the government, might attract more, and highly committed, recruits. 
While these were the dominant motivations for taking up teaching as a career there were other, strictly minority, views that could also usefully inform recruitment policy. Two in five respondents thought it important that primary teaching as a career would fit better with parenthood, while one third had done other work and wanted a change. Work placements for younger students were found to be a very positive pull factor into teaching as a career. Equally, having children enabled many mature students to gain a positive experience of schools and teaching and led them to consider it as an alternative career option. While recruitment might well be enhanced in positive ways by placing far greater emphasis on pull factors into teaching, push factors should also be considered.

\section{'Push' factors into primary teaching}

Gina. I was doing Business Studies, and it was also at [this university] ... and I did that for a year and it just was not what I desired, you know? I was not motivated by anything I was doing, whereas with teaching I was so motivated, especially when you're interacting with children ....

Angela. I had a career break. I stopped work eight years ago - actually, it's nine years ago now - and for the last six years I thought, What could I be doing? and it was a natural progression to go into teaching. I've helped out quite a lot at our local school, as well, and I could see from that that I would enjoy doing something like that. Being around children, trying to work with them, it's not always possible, but trying my best to get them to think and get them to learn.

Guy. I preferred the working atmosphere of teaching. Definitely. The people - I don't know if I should say this or not - but generally I found that the people I've met within teaching have just been more on my sort of wavelength. More so than in industry. It's very backstabbing, very sort of - you know, you've got to be in the Freemasons to get anywhere. Well, it's just I worked within the water industry ... and that's a real sort of shirt-and-collar .... from that job, well, I didn't really want to do it. I just drifted into it.

Gina, Angela and Guy were all career changers but for different reasons and at different stages - Gina after her initial choice of a business studies course, Angela (who had been an architect) through parenthood, and Guy through disillusionment with his first career choice.

Of the male students interviewed, 43 per cent made negative comments about their previous work experience outside education, a high figure considering that not all male respondents had had previous work experience. Their concerns were focused on things like being in the wrong job, being bored with it and seeing it as a dead end in terms of a career. Only 21 per cent of female interviewees said similar things. The work of Jacobs (1993) and Williams and Villemez (1993), on atypical occupational choices in America, support these findings, that is, more men were to be found in female-type jobs than actually aspired to them, at least initially, and many men entered through a 'trapdoor' effect of availability, or convenience, rather than preferred first choice.

We also found that successfully recruited female students attached greater importance to parental responsibilities than male students (significant at $<0.009$ ), and successfully recruited males placed greater importance than females on external limitations such as not being able to get another job or few other job opportunities (significant at $<0.005$ ) or wanting to change their careers (significant at < 0.006).

\section{Concerns or reservations about teaching}

Further insights into these students' views about teaching as a career were gained from their answers to the interview question 'Do you have any reservations about primary teaching as your career?'. The majority of students (54 per cent) claimed to have reservations, while some of those who claimed not to have any actually went on to express some. The main areas in which these students tended to have reservations were confidence (in their ability to do the job well), attitudes (of the 
government and media) and issues (pay, and its link with performance; lack of trust), work load and hours (paperwork; long hours and tiredness). Of the three case studies, Gina claimed to have no concerns, Angela worried about the pressures on teachers, the lack of trust in them and excessive paperwork, and Guy was concerned about the work load, hours and pay.

Gina. None at all, especially after one year.

Angela. As opposed to what? Any other career? Well, I don't like the pressure that teachers are always being put under or the written work they have to do, all the justification .... I know for the first two or three years it's very useful for me to have to write things down, for me to focus my mind on things, but it's very sad that teachers who have been teaching for ten years still have to do all this writing down and their judgement isn't trusted. I think it's very sad that in ten years' time I'll still be doing lesson plans, and so on. In other professions there's more trust in a professional capacity, teachers can act the professional.

Guy. Reservations? Just, the first year is daunting. Low pay. I suppose work load and long hours, responsibilities ... status ... Pay? Yes a little bit, a little bit more would be nice, but $£ 15,500$ is comfortable. It's not great.

\section{Recruitment issues}

One question in the interview schedule asked students to identify what things they thought might discourage people from becoming primary school teachers. Perhaps not surprisingly the responses to this question displayed a marked similarity to those in response to a question concerning encouraging more people into the profession. Table 2 shows the rank order of the seven most often mentioned items for both.

Table 2 Things that discourage people from becoming teachers and things that should be addressed in order to encourage them

\begin{tabular}{lrr}
\hline & \multicolumn{2}{c}{ Rankorder } \\
\cline { 2 - 4 } Item & Discourage & Encourage \\
\hline Pay & 1 & 1 \\
Work load & 2 & 5 \\
Media/image & 3 & 2 \\
Status & 4 & 7 \\
Hours & 5 & - \\
Paperwork & 6 & 3 \\
Stress/pressure & 7 & 13
\end{tabular}

In interview students cited improvements in teachers' pay, less paperwork and the general work load, funding during training and raising the status and image of teaching within the English media and government's eyes as important ways in which to enhance recruitment. Gina was not personally worried about pay but thought it might put people off. In terms of work load she disagreed with many other respondents, thinking it would not discourage others. Angela added to the above list of 'put-offs' with her citation of parental pressure. 
Gina. I think if people are really impatient with children ... yes, patience is ... when I talk to my friends a lot of them say, I haven't got the patience to do what you're doing, so I think that would put people off ... if you're not good at handling children and good around children. Definitely the pay. I wouldn't think of it because it doesn't bother me. The work load? I don't think that would put people off, no. On top of that you get the holidays, and I think that actually encourages people.... I think the government could actually start a campaign, or maybe if wages were put up....

Angela. The low status, the low pay. Parents. They come to school and demand and say, You know no better, and say, My child should be doing this now, etc. And maybe now realising what pressure teachers are under. I didn't realise that before.... I'm not a demanding parent unless there is a good reason.... I don't think people realise what they're letting themselves in for before they go into teaching. I certainly didn't realise the pressure teachers are under.... I don't know. Better pay? A lot of people who look at teaching as a profession, they've got a degree, and then they look and there are all these options there - if I go into teaching it's probably one of the least paid options available, whereas if you go into something - marketing or advertising - you can work yourself up the scale a lot faster. But I don't think pay's everything, and it certainly doesn't help that the teachers have such a bad deal in the press. You know, every time you open a newspaper you hardly ever hear anything good being said about the teachers, it's always, like, Oh, the teachers are on strike again, and The teachers are ... , you know ... and they get a very bad press report, a bit like the architects, actually. I think their status is low. How that could be raised? I don't know. I think on the Continent the status of teachers - people say, Wow! rather than - you know what they think here. That needs to be addressed somehow. I think rather than the government always saying teachers must do this, must do that, and have to prove themselves, and so on, they should occasionally praise them, and say, Yes, they're doing a good job.

Guy. The work load ... well, basically it's people don't like children any more and don't want to deal with them. Low pay.... I felt with the New Labour incentives at first I was quite optimistic, you know ... but I've changed my mind a bit about that. It seems to be wanting to find a scapegoat.... To start with, the money. Status. Teaching support especially ... a very daunting prospect to go and do your first year of teaching whether you've done a four-year course or a one-year course ... I think there should be more integrated sort of ... teacher training ... maybe ... actually get paid for it.... I think my experience ... when you get thrown in at the deep end, you learn quickly but you also learn bad habits, which is one thing you don't want to do in teaching. You learn to survive exactly, you learn strategies....

\section{Summary}

\section{Motivation of these successfully recruited students}

It must be stressed that the findings reported here relate to students who have already been successfully recruited to primary ITE courses in England. They were committed to primary teaching as a career for almost entirely positive, even altruistic reasons. They wanted to teach and saw it as a good career that was challenging, rewarding and socially valuable.

Ideally it would seem most appropriate to 'pull' potential recruits towards teaching (wanting to teach, rewards, challenge, etc.), to motivate them into a positive choice of teaching as a career, rather than to 'push' them (lack of other job opportunities, pay, etc.). The best way of accomplishing this appears from the data to be positive real life and work experience in schools, with real teachers. Experience of, as well as in, schools, providing some feeling for, and understanding of, the nature of teaching, learning, working with children and the classroom environment appear central to the successfully recruited students' decisions to enter the teaching profession. 


\section{Concerns and recruitment strategies}

There were clear expressions of concern about teachers' pay levels and their perceived inappropriateness for attracting either graduate entrants to teaching (through the PGCE route), the more able/highly qualified, or 'breadwinners'.

Respondents identified administrative and bureaucratic overload, low status, negative image and lack of autonomy and trust as other potential 'turn-offs'. These are less positive aspects of teaching which, the successfully recruited suggest, need to be addressed if recruitment is to be enhanced.

There have been some clear and recent political attempts to accentuate the positive aspects of teaching and to attract good publicity for teachers and teaching as a career in England. However, there is still much to be done in raising the status and image of teaching in order to enhance recruitment in general. The financial pressure on PGCE students in training has recently been addressed through the allocation of training salaries, and in-post salary potentially enhanced by the introduction of threshold payments and an extended salary scale (DfEE, 1998). However, training salaries for students taking the PGCE route into primary teaching (and sub-degree labels being attached to the B.Ed. route) will have a negative effect on recruitment to undergraduate courses, precisely those routes through which large numbers of intending primary teachers gain Qualified Teacher Status (QTS). In the long term these financial changes may have a positive overall effect on recruitment into teaching, especially if places on primary PGCE courses are increased, as is likely to happen. However, in the short term, recruitment to undergraduate courses is likely to deteriorate, thereby exacerbating recruitment difficulties.

\section{Male recruitment}

It is clear that a proportion of male (and mature) recruits to teaching, in this study as in others undertaken in the United States (Williams and Villemez, 1993; Jacobs, 1993; Brookhart and Loadman, 1996), come to it later in life, as a second or third-choice career option, perhaps when they are disillusioned with their first choice. If male (and mature) recruitment is to be increased, this diverse and somewhat different pool of potential candidates must be specifically addressed. The recruitment of more men to teaching is recognised to be a key concern of the Teacher Training Authority. Women now account for 83 per cent of the primary teaching force in England (Howson, 1999) and are in the majority in secondary schooling, although it is still the case that men achieve senior posts disproportionate to their numbers within the profession as a whole. There is some evidence (Allan, 1993; Flintoff, 1993; Bonner, 1997, Thornton, 1999) that men, as students and workers, prefer to be seen as achieving and competent and as having high status. The perceived and real public 'denigration' of teachers in England over the past ten years may have effectively discouraged such men from joining a profession that already has relatively low status owing to its association with women's work and young children.

\section{Conclusion}

Despite the concerns outlined above, these successfully recruited students had a predominantly positive view about primary school teaching as a career. Their motivations towards teaching, the pull factors, need to be disseminated widely to encourage others; the positive experiences of schools, classrooms and teachers that led these students into teaching should be made more widely available to others who might also be encouraged to join the profession, and their reservations and concerns should be taken on board as indicators of issues that might deter others from considering primary teaching as a career. 


\section{References}

Allen, J. (1993), 'Male elementary teachers', in C. L. Williams (ed.), Doing 'Women's Work': men in non-traditional occupations, London: Sage.

Barnard, N. (2000), 'Training salary lures men into classrooms', Times Educational Supplement, 19 May, p. 8.

Bonner, C. (1997), What about the Boys? Masculinity, schools and principals, Sydney: New South Wales Principals' Council.

Boulton, P., and Coldron, J. (1998), 'Why women teachers say "Stuff it" to promotion: a failure of equal opportunities?' Gender and Education 10 (2), 149-61.

Brookhart, S., and Loadman, W. (1996), 'Characteristics of male elementary teachers in the United States at teacher education programme entry and exit', Teaching and Education 12 (2), 197-210.

Campbell, E. (2000), ‘Training salary grabs graduates', Times Educational Supplement, 9 June, p. 9.

Campbell, R. J., and Neill, S. (1994), Primary Teachers at Work, London: Routledge. Connell, R. W. (1987), Gender and Power, Cambridge: Polity Press.

Department for Education and Employment (1998) Green Paper: Teachers Meeting the Challenge of Change, London: HMSO.

Evans, L. (1998), Teacher Morale, Job Satisfaction and Motivation, London: Chapman.

Flintoff, A. (1993), 'One of the boys? Gender identities in physical education initial teacher education', in I. Sirag-Blatchford (ed.), 'Race', Gender and the Education of Teachers, Buckingham: Open University Press.

Gates, N. (1999), 'Undergraduate teacher training: a case of terminal decline?' SCETT News, autumn (2), pp. 4-5.

House of Commons, Education and Employment Committee (1997), First Report: Session 1997-99. The Quality of ITT Students and those entering Teaching, London: HMSO.

Howson, J. (1998), 'Where have all the young men gone?' Hot Data, Times Educational Supplement, 6 November, p. 22.

- (1999), 'Men begin to turn primary corner', Hot Data, Times Educational Supplement, 22 October, p. 25.

Jacobs, J. (1993), 'Men in female-dominated fields: trends and turnover', in C. L. Williams (ed.), Doing 'Women's Work': men in non-traditional occupations,

London: Sage.

Johnston, J., McKeown, E., and McEwen, A. (1998), Gender Factors in Choosing Primary School Teaching, Belfast: Northern Ireland Equal Opportunities Commission.

Jones, M. L. (1990), 'The attitudes of men and women primary school teachers to promotion and educational management', Educational Management and Administration 18 (3), 11-16.

Kenway, J., and Willis, S. (1998), Answering Back, London: Routledge.

Mac an Ghaill, M. (1994), The Making of Men: masculinities, sexualities and schooling, Buckingham: Open University Press. 
McAvoy, D. (2000), 'Education degree prejudice', Times Educational Supplement, 9

June, p. 23.

Nias, J., Southworth, G., and Yeomans, R. (1989), Staff Relationships in the Primary School: a study of organisational cultures, London: Cassell.

Owen, C., Cameron, C., and Moss, P., eds (1998), Men as Workers in Services for

Young Children, London: Institute of Education, University of London.

Penn H., and McQuail, S. (1997), Childcare as a Gendered Occupation, DfEE

Research Report 22, London: HMSO.

Reid, I., and Thornton, M. (2000), Students' Reasons for Choosing Primary School

Teaching as a Career, Aldenham: Centre for Equality Issues in Education, University of Hertfordshire.

Richards, L., and Richards, T. (1997), QSR NU*DIST, Version 4.0 User Guide, second edition, London: Sage.

Ruxton, S. (1992), What's he doing at the Family Centre? London: National Children's Homes.

Skelton, C. (1991), 'A study of the career perspectives of male teachers of young children', Gender and Education 3 (3), 278-89.

Tabberer, R. (2000), 'Golden opportunities', Times Educational Supplement, 19 May, p. 17.

Thornton, M. (1998), Subject Specialists: Primary Schools, UCET Occasional Paper 10, London: Universities Council for the Education of Teachers.

- (1999), 'Reducing wastage among men student teachers in primary courses: a male club approach', Journal of Education for Teaching 25 (1), 41-53.

Williams, L. S., and Villemez, W. J. (1993), 'Seekers and finders: male entry and exit in female-dominated jobs', in C. L. Williams (ed.), Doing 'Women's Work', London: Sage.

\section{Address for correspondence}

Dr Mary Thornton, University of Hertfordshire, ,

.E-mail m.e.thornton@herts.ac.uk 